New Zealand and Australia call for wider access to knowledge

[SYDNEY] Australia's delegation to the World Conference on Science in Budapest is expected to urge Unesco to prioritize access to knowledge for developing countries.

The New Zealand delegation will call on Unesco to widen the participation of women and indigenous peoples in science. New Zealand also plans a national conference to be held within ten months of the Budapest meeting to implement its recommendations.

Both delegations will call on Unesco to support Pacific island countries in their efforts to manage their marine resources, slow down climate change and mitigate natural disasters.

The Australian delegation will be headed by John Zillman, director of the Bureau of Meteorology and president of the World Meteorological Organization. The New Zealand group will be led by Paul Ramsay, head of the international affairs branch of the Ministry of Research, Science and Technology. Both delegations will include representatives of indigenous peoples (Aboriginal and Maori) as well as doctoral students.

Delegates hope to initiate an international programme for "enhancing the professional quality of reporting of science, engineering and technology in the mass media". They will seek the agency's support for a scheme similar to the planned International Centre for Science Communication in London.

Full text: http://helix.nature.com/wcs/a44.html

\title{
Non-governmental groups welcomed as observers
}

[LONDON] Invitations to attend the World Conference on Science in Budapest later this month have gone out to 150 nongovernmental organizations (NGOs). Most of these have gone to organizations of scientists, although Unesco officials say that other groups, such as environmentalist NGOs, are welcome to apply.

The NGOs will only have observer status at the conference. But they may be allowed to address its plenary sessions and to make interventions during debates, say officials.

Representatives of Greenpeace and Friends of the Earth are expected to attend, although there is no environmentalist voice on the main preparatory committee. This was set up to coordinate NGO responses to the conference draft documents. Mauricio Iaccarino, Unesco's assistant director-general for science, said in London this month that "no anti-science or pseudo-science people have been invited [to Budapest]".

The NGO committee is made up of representatives of the Third World Academy of Sciences, the International Council for Social Sciences, the World Federation of Scientific Workers, and the International Council for Philosophy and Human Sciences. It was asked to begin consulting NGOs at the end of May.

One senior member of a science NGO says there are good reasons for restricting attendance from environmental NGOs, even though these have had a strong presence at meetings of other UN agencies, such as the World Health Organization and the environment conventions. "There will be no mass jamboree. The meeting will be more focused, and we will get things done."

A Unesco spokesman says there is no attempt to exclude environmental groups, adding that he is still processing applications from those who want to attend. He says that science-based organizations are predominant because of their affiliation to Unesco or to ICSU, the International Council for Science, which are jointly organizing the conference. He points out that NGOs are often members of official government delegations.

NGOs have been allocated two half-day sessions during the conference, on 27 and 28 June, to comment on and suggest amendments to the draft Declaration and Framework for Action documents.

Unesco has also set up a committee to coordinate the NGO community's responses to the draft conference documents, with a deadline for submissions of 20 June, says Andre Jaegle, president of the Paris-based World Federation of Scientific Workers, and a member of the committee.

Conference secretary Howard Moore says: "We hope there will be some controversy, and that it is not just a talking shop for politicians."

Full text: http://helix.nature.com/wcs/a43.htm

\section{Private research and public access must go together, says Mayor}

[BUDAPEST] The most crucial issue facing the World Conference on Science later this month will be how to defend public access to scientific knowledge while benefiting from private investment in research, says Federico Mayor, the director-general of Unesco.

"Science is part of the crucial question of how to ensure that the 'knowledge society' does not become a new form of imperialism, placing developing countries in new chains," says Mayor in an opinion article written for Nature's web-based coverage of the conference.

He says that finding solutions to intricate problems will take time. But action can be taken immediately, and issues do not have to be couched in confrontational terms.

"For example, the argument that biotechnology is the key to greater food production has been countered by claims that it is in fact enhanced democracy that increases food production and distribution," says Mayor. "But we need both; this, surely, has to be the basis of the required relationship between science and society."

Mayor suggests that the two central documents for the Budapest meeting — the Declaration and the Framework for Action - connect up vision, principles and practice in a "shared dynamic", expressed in every area from forms of funding and training, to strategies for networks and communication.

In innovation and technology foresight, for example, the renewed commitment by governments to fundamental research being sought in Budapest by the scientific community "should ensure that basic science continues to produce the new knowledge without which innovation will ultimately dry up," he says.

^๑) 1999 Macmillan Magazines Ltd
New initiatives in the transfer of scientific knowledge, expected to be announced in Budapest, "will attempt to open up global access to the huge store of existing knowledge". And a redefinition of wealth creation to include the massive indirect wealth created by sustainability and preventive measures "must be the driving vision behind science for development".

This coherent, global momentum "requires every single participant at the World Conference on Science and stakeholders in science around the world to join forces and play a role," says Mayor. A universal readiness to get involved in the many initiatives now emerging "can tip the balance and possibly even reverse today's extraordinary concentration of science within a few countries". Full text: http://helix.nature.com/wcs/c21.html 